\title{
Ancestral Caddo Ceramic Vessels from the J. B. Sparkman Site (41HP26), Hopkins County, Texas
}

Timothy K. Perttula

Heritage Research Center, Stephen F. Austin State University

Follow this and additional works at: https://scholarworks.sfasu.edu/ita

Part of the American Material Culture Commons, Archaeological Anthropology Commons, Environmental Studies Commons, Other American Studies Commons, Other Arts and Humanities Commons, Other History of Art, Architecture, and Archaeology Commons, and the United States History Commons

Tell us how this article helped you.

This Article is brought to you for free and open access by the Center for Regional Heritage Research at SFA ScholarWorks. It has been accepted for inclusion in Index of Texas Archaeology: Open Access Gray Literature from the Lone Star State by an authorized editor of SFA ScholarWorks. For more information, please contact cdsscholarworks@sfasu.edu. 


\section{Ancestral Caddo Ceramic Vessels from the J. B. Sparkman Site (41HP26), Hopkins County, Texas}

\section{Creative Commons License}

\section{(c) (1) \&}

This work is licensed under a Creative Commons Attribution-NonCommercial 4.0 International License 


\title{
Ancestral Caddo Ceramic Vessels from the J. B. Sparkman Site (41HP26), Hopkins County, Texas
}

\author{
Timothy K. Perttula
}

\section{INTRODUCTION AND CONTEXT OF THE VESSELS}

Two ancestral Caddo vessels were excavated by a J. B. Sparkman from a burial that had been exposed by erosion. The burial was found on the site in the Caney Creek valley in the upper Sabine River basin near the community of Black Oak in southeastern Hopkins County, Texas (Figure 1). The University of Texas purchased the two vessels from Mr. Sparkman in May 1931.

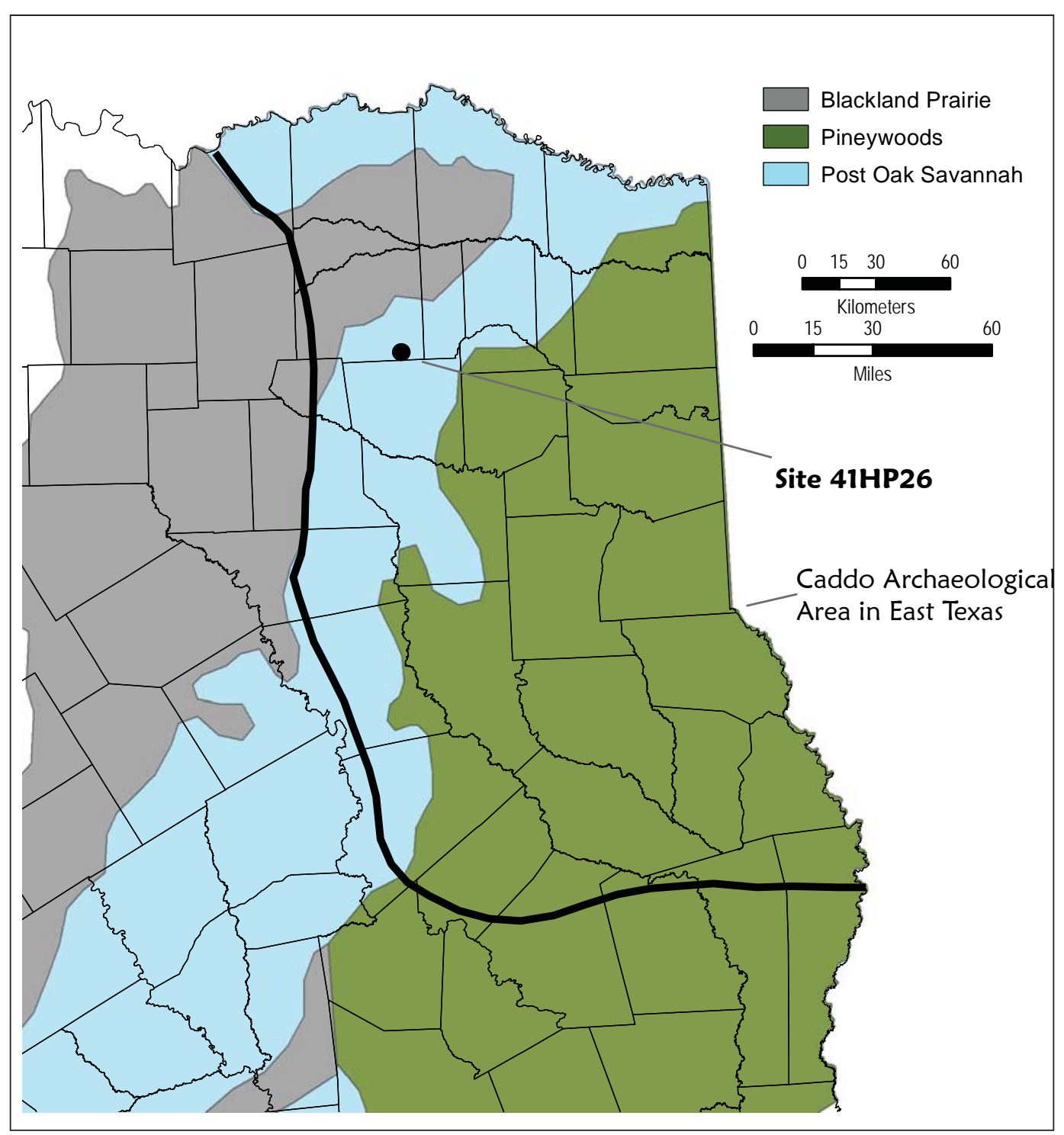

Figure 1. Location of the J. B. Sparkman site (41HP26) in East Texas. 


\section{Ceramic Vessels}

SITE NAME OR SITE NUMBER: J. B. Sparkman, 41HP26

VESSEL NO.: 41HP26-1

VESSEL FORM: Bottle with a carinated body

NON-PLASTICS AND PASTE: grog

RIM AND LIP FORM: Direct rim and a rounded-exterior folded lip

CORE COLOR: $\mathrm{G}$ (fired in a reducing environment and cooled in the open air)

INTERIOR SURFACE COLOR: dark grayish-brown

EXTERIOR SURFACE COLOR: brown; fire clouds on the rim, body, and base

WALL THICKNESS (IN MM): rim, $5.0 \mathrm{~mm}$

INTERIOR SURFACE TREATMENT: none

EXTERIOR SURFACE TREATMENT: burnished

HEIGHT (IN CM): 11.5

ORIFICE DIAMETER

(IN CM): 3.7

DIAMETER AT

BOTTOM OF RIM

OR NECK (IN CM): 3.6

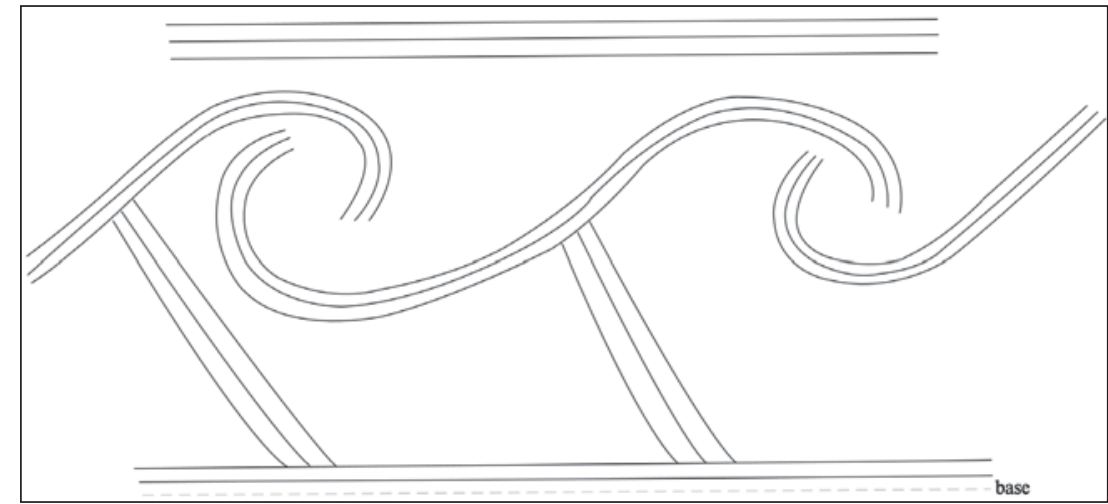

Figure 2. Taylor Engraved bottle from the J. B. Sparkman site (41CP26).

BASE DIAMETER (IN CM) AND SHAPE OF BASE: 3.7; circular and concave

ESTIMATED VOLUME (IN LITERS): 0.17

DECORATION (INCLUDING MOTIF AND ELEMENTS WHEN APPARENT): The vessel has a series of four interlocking engraved scrolls comprised of three closely-spaced engraved lines (cf. Suhm and Jelks 1962:Plate 76). Attached to each of the lower portions of the interlocking scrolls are a series of three diagonal engraved lines that extend to the upper of two horizontal engraved lines encircling the base. At the top of the vessel body are three horizontal engraved lines (Figure 2).

PIGMENT USE AND LOCATION ON VESSEL: none

TYPE AND VARIETY (IF KNOWN): Taylor Engraved 
SITE NAME OR SITE NUMBER: J. B. Sparkman (41HP26)

VESSEL NO.: 41HP26-2

VESSEL FORM: Carinated bowl

NON-PLASTICS AND PASTE: grog

RIM AND LIP FORM: Inverted rim and rounded lip

CORE COLOR: B (fired and cooled in a reducing or low oxygen environment)

INTERIOR SURFACE COLOR: grayish-brown

EXTERIOR SURFACE COLOR: very dark grayish-brown

WALL THICKNESS (IN MM): rim, $5.1 \mathrm{~mm}$

INTERIOR SURFACE TREATMENT: smoothed

EXTERIOR SURFACE TREATMENT: burnished

HEIGHT (IN CM): 7.6

ORIFICE DIAMETER (IN CM): 10.2

DIAMETER AT BOTTOM OF RIM OR NECK (IN CM): 11.6

BASE DIAMETER (IN CM) AND SHAPE OF BASE: 6.4; circular and flat

ESTIMATED VOLUME (IN LITERS): 0.47

DECORATION (INCLUDING MOTIF AND ELEMENTS WHEN APPARENT): Underneath the single horizontal engraved line under the lip on the narrow rim panel of the carinated bowl, the panel is divided into at least nine sections by a series of three closely-spaced vertical lines (cf. Suhm and Jelks 1962:Plate 711) (Figure 3). The vessel lip is notched.

PIGMENT USE AND LOCATION ON VESSEL: none

TYPE AND VARIETY (IF KNOWN): Simms Engraved

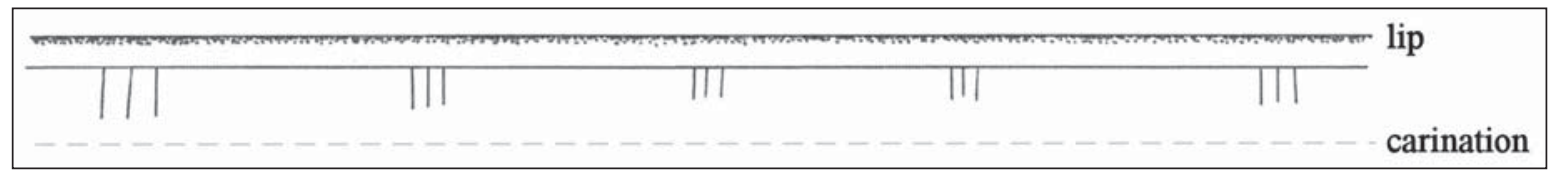

Figure 3. Simms Engraved carinated bowl from the J. B. Sparkman site (41HP26). 


\section{SUMMARY AND CONCLUSIONS}

J. B. Sparkman excavated a Caddo burial with two ceramic vessel funerary offerings from a site in the Caney Creek valley in the upper Sabine River basin in East Texas. These vessels - a Taylor Engraved bottle with an interlocking scroll and a Simms Engraved carinated bowl with a series of three short vertical engraved lines and a notched lip. The burial likely dates to the latter part of the Titus phase, ca. A.D. 15501680 , as these ceramic decorative styles are present in sites in this area only during that temporal interval (see Perttula et al. 1993).

\section{ACKNOWLEDGMENTS}

I appreciate the assistance of Jonathan Jarvis at the Texas Archeological Research Laboratory, The University of Texas at Austin for providing access to their records and collections. Lance Trask prepared the figures in this article.

\section{REFERENCES CITED}

Perttula, T. K., B. D. Skiles, and B. C. Yates

1993 The Goldsmith Site (41WD208): Investigations of the Titus Phase in the Upper Sabine River Basin, Northeast Texas. Bulletin of the Texas Archeological Society 61:139-191.

Suhm, D. A. and E. B. Jelks (editors)

1962 Handbook of Texas Archeology: Type Descriptions. Special Publication No. 1, Texas Archeological Society, and Bulletin No. 4, Texas Memorial Museum, Austin. Reprinted in 2009, Gustav's Library, Davenport, Iowa. 